\title{
Miranda
}

Revue pluridisciplinaire du monde anglophone /

Multidisciplinary peer-reviewed journal on the English-

speaking world

$12 \mid 2016$

Mapping gender. Old images ; new figures

\section{Ann C. Colley, Wild Animal Skins in Victorian Britain: Zoos, Collections, Portraits and Maps}

Laurence Talairach-Vielmas

URL: http://journals.openedition.org/miranda/8039

DOI: 10.4000/miranda.8039

ISSN: 2108-6559

Publisher

Université Toulouse - Jean Jaurès

Electronic reference

Laurence Talairach-Vielmas, "Ann C. Colley, Wild Animal Skins in Victorian Britain: Zoos, Collections,

Portraits and Maps ", Miranda [Online], 12 I 2016, Online since 26 February 2016, connection on 16 February 2021. URL: http://journals.openedition.org/miranda/8039 ; DOI: https://doi.org/10.4000/ miranda.8039

This text was automatically generated on 16 February 2021.

\section{(c) $(1)$}

Miranda is licensed under a Creative Commons Attribution-NonCommercial-NoDerivatives 4.0 International License. 


\title{
Ann C. Colley, Wild Animal Skins in Victorian Britain: Zoos, Collections, Portraits and Maps
}

\author{
Laurence Talairach-Vielmas
}

\section{REFERENCES}

Ann C. Colley, Wild Animal Skins in Victorian Britain: Zoos, Collections, Portraits and Maps (Farnham: Ashgate, 2014), 206 p, ISBN 978-1-4724-2778-6

1 From the eighteenth century and throughout the Victorian period wild animals were recurrently exhibited in Britain. Locked up behind bars in zoological gardens or menageries, these exotic animals entertained children and adults from all social classes just as they emblematized the global expansion of the British empire. But the Victorians particularly assigned meanings to the wild skins that were exhibited throughout the country, as Ann C. Colley's Wild Animal Skins in Victorian Britain argues. Using literary texts, zoo archives, scientific treatises, diaries, letters, travel narratives and pictures, Colley proposes a view of the significance of these wild skins, often looking at them through recent theorizing about skin so as to understand how the Victorians perceived wild animal skins.

2 In the first chapter, Colley focuses on the Belle Vue Zoo in Manchester, as a significant example of collections of wild skins, at a time when zoological gardens opened throughout Europe. Founded in 1836, the Belle Vue Zoo exhibited live animals as well as stuffed beasts. Shaped as a sequence of portraits, the menagerie illuminated Britain's imperial expansion and power. As Colley recalls, zoological gardens were often satirised in cartoons all through the century, Punch caricatures regularly foregrounding the collapse of boundaries between humans and beasts. This trend reached a climax after the publication of Charles Darwin's On the Origin of Species by Means of Natural Selection, or the Preservation of Favoured Races in the Struggle for Life in 1859. This was 
particularly illustrated by cartoons such as Edward Linley Sambourne's "Designs after Nature" (1867-76), for instance. Although Colley is not concerned with the impact of evolutionary theory on contemporary representations of exhibited beasts, she nonetheless notes how popular fears regarding the potentially simian origin of humans were suppressed in illustrations of the time, artists being often asked, she contends, not to hint at humans' beastly origins even before mid-century. Thus, the assemblage of portrait galleries at Belle Vue Zoo, as Colley makes clear throughout the chapter, stressed wider debates related to the permeable boundaries between humans and animals and highlighted the way in which skin was related to the issue of identity. Furthermore, the popular taste for natural history, frequently captured by Victorian literature through images of collectors and collections (Colley cites the beetle collection in Oscar Wilde's The Picture of Dorian Gray [1890] as a case in point), signalled that more and more species were discovered everyday, rendering all systems of classification (almost) unpredictable. Colley looks at Edward Lear's Book of Nonsense (1846) as a good artistic example pointing out the impossibility of naming and classifying specimens, and many of the other illustrations she refers to, such as cartoons by George du Maurier ("The Keeper's Nightmare" (1871)), or R. M. Balantyne's novel, The Gorilla Hunter (1876), inspired by Paul du Chaillu's Explorations and Adventures in Equatorial Africa (1861), are convincing.

3 In Chapter 2, Colley recalls the difficulties that collectors and naturalists encountered when they attempted to collect and preserve exotic specimens. Skins were often the only means of studying wild animals to map out "a more inclusive portrait of the natural world" (62). The portrait of the British empire that wild skins enabled scientists to put together, however, was more often than not impeded by predators, such as insects, or preserving techniques that damaged the skins. The chapter provides examples of naturalists' experiences with wild skins (Richard Owen, Alfred Russel Wallace, Charles Waterton), and draws attention to the difficulties some of them encountered when trying to transport live animals or skins home. In particular, the passages on the $13^{\text {th }}$ Earl of Derby (Edward Smith Stanley), who collected skins and kept a menagerie, or on Elizabeth Hornby's travels in South America, offer stimulating glimpses into the lives of mid-nineteenth-century natural history collectors.

In Chapter 3, on Victorian animal portraiture, Colley looks at a piece of Edward Lear's nonsense, informed by Victorian travellers' experiences. Lear had been commissioned to paint watercolour portraits of the animals in the Knowsley Menagerie at Knowsley Hall (the Earl of Derby's estate), and his "Story of the Four Little Children Who Went Around the World" was undoubtedly inspired, Colley suggests, by his stay at Knowsley Hall and its culture of collecting, identifying or preserving skins. The piece "exposes the fate of numerous grand, exotic mammals whose bodies were mounted and exhibited by hunters and scientific institutions" (90) through its representation of a rhinoceros who falls victim to colonialism, at a time when many exotic animals were turned into pieces of furniture, as Colley explains. As a result, Lear's creatures often rebel against the imperial gaze, and many of them are "liberated beings" (116) in illustrations which reverse the colonial gaze and stare back. For Lear's works, Colley contends, shows how uncomfortable the artist was "with the scientific and imperialistic practices of caging, classifying, and turning these animals into commodities", using his art, therefore, "to revive the life residing within his subjects' skin by riddling them of the suffocating details required by the commission" (120). 
In Chapter 4, Colley looks at guides that reported the numerous ways in which visitors interacted with the animals in zoological gardens (either by touching them, riding them, being licked or even teasing and injuring the animals), such as the Picturesque Guide Through the Regent's Park (1829) or The Pictorial Museum of Animated Nature (184345). She probes the significance of touch in these encounters and analyses two Victorian paintings - Sir Lawrence Alma-Tadema's In the Tepidarium (1881) and James McNeill Whistler's Symphony in White, $n^{\circ} 1$, The White Girl (1862)-which both depict an intimate moment of contact with an animal. Some of Colley's conclusions here are unconvincing or fail to add to previous analyses of Whistler's or Alma-Tadema's works, such as when she suggests that because touch was used for knowledge, these tactile encounters "briefly linked the viewer with the exotic", that "Whistler's painting realizes the yearning of those zoo visitors who wished to have their fingers licked by wolves" (145), or that the eroticism informing both paintings hint at the "wild" nature of woman.

6 In her last chapter, Colley draws comparisons between the ways in which the Victorians displayed animal skins and how they attempted to map the world around them. The Victorian cartographic imagination was inspired by many missionary and explorers, like David Livingstone, and hunting maps which appeared at the time, such as the Map of the Shooting Districts between Shanghai and Wuhu (1893). To build her case, Colley focuses on Thomas Hardy - famous for his fictional maps - and examines more closely Tess of the d'Urbervilles (1891). Her contention is that Hardy used skin "to chart the topography" (149) of Tess's downfall, but the analysis remains superficial on the whole. In the second part of the chapter, Colley looks at how G. M. Hopkins used animals and skin to describe his surroundings and illuminates the impact of zoogeography on his poetry. As she shows, Hopkins's description of his environment often combined humans, animals and landscapes and his cartographic imagination was "not simply tied to imperialistic notions of mastery" (181).

7 Wild Animal Skins in Victorian Britain brings together people(s), objects and themes typical of the Victorian period in a stimulating way, Colley using a wide variety of material sources. However, some of the topics, pictures or texts under study are frequently reviewed too quickly, sometimes giving an impression of Victorian bric-abrac-an image of collected pieces that lack a coherent whole or which are forced into fitting the pattern. The lack of conclusion also adds to this impression, but Colley's study should nonetheless prove inspiring to students and cultural historians interested in the period.

\section{INDEX}

Keywords: Victorian, animals, exhibition, exotic, zoos, collections, cartography

Mots-clés: animaux, cartographie, collections, époque victorienne, exposition, exotique, zoos 


\section{AUTHORS}

\section{LAURENCE TALAIRACH-VIELMAS}

Professeur des Universités

Université de Toulouse - Jean Jaurès

laurence.talairach-vielmas@univ-tlse2.fr 